\section{BIZTOSÍTÁSI KÖTELEZETTSÉGEK FAIR ÉRTÉKELÉSE IDŐ- ÉS PIACKONZISZTENS AKTUÁRIUSI ÉRTÉKELÉSEK}

Romvári Petra, romvari.petra@hotmail.com

A Magyar Aktuárius Társaság 2018-ban Romvári Petrának itélte oda a Biztositásmatematika Ifjú Mestere dijat.

\section{ÖSSZEFOGLALÓ}

Biztosítóként fontos feladat annak meghatározása, hogy egy általunk kínált biztositási termékért milyen árat kérjünk. A hagyományos értékelési módszerek nagyrészt azon a hozzáálláson alapulnak, hogy ezek a termékek kockázatként kizárólag egyfajta „aktuáriusi kockázatot” foglalnak magukban, azaz véletlenségük pusztán egy kapcsolódó biztosítási folyamat (például túlélésszám) alakulásától függ, de a piactól magától nem.

A biztosítók ezzel szemben nagy számban kínálnak olyan termékeket, melyek kockázata már összefüggésben van bizonyos piacon kereskedett termékek áralakulásával is. Természetes igényként vetődhet így fel, hogy a kockázat értékelésekor és árazásakor az említett piaci kockázat is legyen figyelembe véve. İrásomban a vonatkozó irodalom feldolgozásával arra a kérdésre kerestem a választ, hogy milyen lehetséges módokon lehet kezelni a megjelenő kockázatkettőst.

Jelen cikk a Budapesti Corvinus Egyetem biztositási és pénzügyi matematika mesterszakának aktuárius specializációján, a 2018. júliusi záróvizsgán megvédett szakdolgozat alapján készült.

\section{SUMMARY}

For an insurance company, determining the fair price of an insurance product is crucial. Standard actuarial premium principles are usually based on the concept that these products solely contain "actuarial risk", or in other words, the possible dependence on the financial market is neglected.

However, many products offered do involve financial risk. While giving a brief overview of the related literature, in this article we're looking for the answer to how to evaluate such payoffs accordingly, taking into consideration both their financial and non-financial risk.

The article is based on my thesis written at the actuarial specialization of the Actuarial and Financial Mathematics MSc of Corvinus University of Budapest, defended in July 2018.

Kulcsszavak: díjelvek, piackonzisztencia, időkonzisztencia

Key words: actuarial valuation principles, market-consistency, time-consistency

\section{JEL: G22}

DOI: $10.18530 /$ BK.2018.4.52

http://dx.doi.org/1018530/BK.2018.4.52

\section{Bevezetés}

A biztosítási termékek palettáján nagy számban vannak jelen olyan termékek, melyek kockázata nem csupán valamilyen biztosítási folyamat sztochasztikájából fakad, hanem bizonyos piacon kereskedett termékek áralakulásának véletlenségéből is. Példaként említhetök ezek között a unit-linked biztosítások, valamint a garanciális biztosítási kifizetések is. Habár sokfajta konstrukció foglal magában az aktuáriusi mellett piaci kockázatot is, a kétféle kockázattípus együttes értékelésére és kezelésére a biztosítók még mindig viszonylag kis hangsúlyt fektetnek.

Ebben az írásban nagyrészt Antoon Pelsser, Ahmad Salahnejhad Ghalehjooghi és Mitja Stadje vonatkozó munkásságának feldolgozásával egy lehetséges módszer kerül bemutatásra, mely már kezelni tudja a megjelenő kockázatkettőst: megismerkedünk az úgynevezett idő- és piackonzisztens aktuáriusi értékelésekkel. Ilyen értékeléseket nyerhetünk például a már széleskörűen használt aktuáriusi díjelvek kiterjesztéseivel (ezeket egyaránt kiterjesztjük időkonzisztens és piackonzisztens irányba). Ahhoz azonban, hogy ilyen értékelésekkel érdemben foglalkozhassunk, mindenekelőtt szükségünk van a fogalmi keretek felállítására.

Ezek lehetséges eszközt kínálnak arra, hogy aktuáriusi és pénzügyi kockázat kettősét együttesen is kezelni tudjuk.

Elsőképp az időkonzisztencia fogalmát vezetjük be: mit értünk alatta, miért adódhat természetes elvárásként egy értékeléssel szemben, illetve hogyan valósítható meg az aktuáriusi díjelvek időkonzisztens kiterjesztése? Ezt követően röviden a piackonzisztencia fogalmára is kitérünk, és megnézzük, az hogyan érvényesíthető egy biztosító keretrendszerében. Mindkét fogalom jelentésének tisztázását követően pedig rátérhetünk olyan értékelések tanulmányozására is, melyek egyaránt idő- és piackonzisztensek.

Ezek már lehetséges eszközt kínálnak arra, hogy a korábban említett aktuáriusi és pénzügyi kockázat kettősét együttesen is kezelni tudjuk.

A fogalmi keretek felállítását követően két példa bemutatásán keresztül illusztráljuk, hogyan írható fel és használható az általunk megismertetett módszer konkrét biztosítási szituációkban.

Végül röviden szót ejtek arról is, hogy milyen gyakorlati jelentőséggel bírhat az idő- és piackonzisztens értékelések biztosítói alkalmazása.

Árazás a biztosítási folyamat fejlődésdinamikájának figyelembe nem vételével

Az aktuáriusi munka legfontosabb feladatai közé tartozik a biztosítási szerződések árazása, legyen szó akár egy konkrét szerződésről, akár egy teljes állomány vizsgálatáról. Vegyünk egy egyszerű példát: mennyit kérjünk egy $T$ tartamú elérési biztosításért? Vagy 
általánosabban: vizsgáljunk egy olyan homogén portfóliót, amelyben valamennyi szerződés kifizetése a $T$. időpillanatban esedékes! Felmerül a kérdés, hogy mennyi legyen ennek az ára. A kérdés lehetséges megválaszolásának széles irodalma van, ugyanakkor a megközelítéseknek rendszerint közös jellemzője, hogy az árazáshoz kizárólag a kifizetés $T$. időpontbeli mutatóit veszik figyelembe. Gondolhatunk akár a hagyományos dijkalkulációs elvekre: mind a várható érték elv, mind a szórásnégyzet elv, mind a szórás elv alapvetően a $T$. időpontra vonatkozó várható érték, illetve szórásnégyzet (vagy szórás) függvényeként írják fel az árat, de a háttérben meghúzódó biztosítási folyamat (például egy elérési biztosítás esetében a túlélőszám-folyamat) fejlődésdinamikájával magával, a folyamat időbeni változásának jellemzőivel nem foglalkoznak.

Ahogy Thomas Møller is hangsúlyozza Indifference pricing of insurance contracts in a product space model címü cikkének bevezetőjében, az ilyen módszerek azért is vetnek fel problémát, mert elméletben nem engedik, hogy a biztosító a $(0, T)$ intervallumon reagáljon a kockázatra és a biztosítási folyamat alakulására. Így a vizsgálódásból kizárják a viszontbiztosítási és pénzügyi piac meglétét, noha a valóságban kínálkozik lehetőség az azokon történő kereskedésre, s ezáltal a kockázat lehetséges mérséklésére és megfelelőbb kezelésére.

Az Antoon Pelsser és Ahmad Salahnejhad Ghalehjooghi által tárgyalt időkonzisztens aktuáriusi értékelés (Time-Consistent Actuarial Valuations, 2015) a statikus vizsgálódás miatt felvetődő problémára reflektál. A szerzők ötletének lényege, hogy a már széles körben ismert és használt aktuáriusi díjelvek alkalmazásából indulnak ki, de azokat nem a szokványos módon írják fel, hanem időkonzisztensen kiterjesztve, aminek köszönhetően már a korábban elhanyagolt fejlődésdinamika is figyelembe lesz véve.

\section{Az időkonzisztencia fogalma}

Legyen $(\Omega ; A ; P)$ valószínűségi mező, $y(t)$ egy ezen értelmezett biztosítási folyamat, $A_{t}: \sigma(y r \mid 0 \leq r \leq t)$ filtráció. Azt az esetet vizsgáljuk, amikor az állományra vonatkozó kifizetés a $T$. időpillanatban fog történni, és a portfólió akkori kifizetése a szóban forgó biztosítási folyamat $T$. pontbeli értékének, $y(T)$-nek lesz a függvénye: $f(y(T)$ ).

Példaképp vegyünk egy elérési biztosítást! Adott számú szerződővel indulunk: akik közülük megélik $T$-t, ők kifizetésre jogosultak, a többiek viszont nem. A szerződők számát modellezzük esetünkben a biztosítási folyamattal, $y$-nal: $y(0)$ szerződővel indulunk, a $t$. időpillanatban $y(t)$ a még életben lévők száma, s végül a $T$-t megélő $y(T)$ számú biztosítottnak tartozunk kifizetéssel. A rájuk vonatkozó teljes kifizetés tehát $y(T)$ függvénye: $f(y(T))$.

Jelöljük az árat $\pi$-vel! $\pi: L^{2}\left(A_{T}\right) \rightarrow L^{2}\left(A_{t}\right)$ feltételes kockázati mérték. $\pi$-ről akkor mondjuk, hogy időkonzisztens, ha teljesül rá az alábbi:

$\pi[f(y(T)) \mid t, y(t)]=\pi[\pi[f(y(T)) \mid s, y(s)] \mid t, y(t)] \quad \forall 0 \leq t<s \leq T$ esetén.

Ez a felírás a feltételes várható érték toronyszabályának megfelelőt követel meg. Azt hivatott kifejezni, hogy ha a $t$. időpillanatban adnánk el a portfóliót, akkor ugyanannyit kérnénk érte, mintha a $t$. időpillanatban azért kérnénk árat, hogy az $s$. időpillanatban $(0 \leq t<s \leq T)$ megváljunk az akkor már $\pi(s, y(s))$ árú portfóliótól. A fenti formalizálja az időkonzisztencia követelményét: egyetlen időhorizonton árazva ugyanazt az árat kéne megszabnunk, mintha az időhorizontot tovább osztva pontról pontra áraznánk. Az időkonzisztens értékelés tehát arról fog szólni, hogy az árfüggvénynek valamennyi belső pontjára vonatkozóan eleget kell tennie az időkonzisztencia feltételének.

\section{Az időkonzisztens árazás mint módszer alapjai}

Antoon Pelsser és Ahmad Salahnejhad Ghalehjooghi cikke alapján (Time-Consistent Actuarial Valuations, 2015) mutatom be ebben az alfejezetben a címben jelölt módszer alapjait.

Az időkonzisztens árazás lényege, hogy az időkonzisztencia feltételét meg kell követelnünk. Beárazandó egy szerződés, amelynek kifizetése a T. időpontban esedékes. Hangsúlyozandó, hogy az időkonzisztencia maga egy módszer, de önmagában nem biztosít árazó formulát, így nekünk kell még külön megadni mellé egy árazási eszközt. Ez az eszköz lehet például a szokásos aktuáriusi díjelvek valamelyike (szórásnégyzet elv, szórás elv stb.), de azt már nem a hagyományos, statikus módon kell felírnunk, hanem az időkonzisztencia módszerével.

\section{Az időkonzisztencia maga egy módszer, de önmagában nem biztosít árazó formulát.}

Az időkonzisztens árazás megvalósítási módja, hogy a kezdő- és végpont által meghatározott időintervallumot kisebb, $\Delta t$ hosszú intervallumokra osztjuk. Ezeken a kis intervallumokon már tudunk a hagyományos módon árazni, vagyis az időhorizontot tovább nem osztva felírhatjuk a szokásosan alkalmazott aktuáriusi díjelveinket a kezdőpont végpont szerinti beárazására. Elsőképp az utolsó intervallumon teszünk így: $T$ - $\Delta t$-ben határozzuk meg az arra vonatkozó feltétellel (vagyis a feltételes várható érték és szórásnégyzet felírásával), hogy mennyit kérünk a $\Delta t$ idő elteltével, $T$-ben esedékes portfóliókifizetésért. Ez a szórásnégyzet elv esetében illusztrálva ( $\alpha$-val jelölve a díjelv paraméterét):

$\pi_{T-\Delta t}(f(y(T)))=E(f(y(T)) \mid T-\Delta t, y(T-\Delta t))+\frac{1}{2} \alpha D^{2}(f(y(T)) \mid T-\Delta t, y(T-\Delta t))$,

ahol $\alpha \geq 0$. Az utolsó időintervallumra szóló feltételes árazással így meg is lennénk.

Ezt követően haladhatunk hátulról előre, a következő lépésben az előzőhöz hasonlót fogunk felírni, csak immáron a $[T-2 \Delta t, T-\Delta t]$ intervallumra: a $T-2 \Delta t$-beni feltételes várható érték és szórásnégyzet felírásával adjuk meg a $T-2 \Delta t$ pontbeni árat a $T$ - $\Delta t$-beni "kifizetésre” vonatkozóan (ez a „kifizetés” a T-beli ténylegesen megvalósuló kifizetésből levezetett $\pi T-\Delta t$ árfüggvényből származik). A felírt követelmény biztosítja, hogy az időkonzisztencia elvárása teljesüljön a $T-2 \Delta t, T-\Delta t$ és $T$ pontokat illetően. Megegyezően folytathatjuk a hátulról előrefele haladást, mígnem végül elérünk a kezdőpontig, $t$-ig, ezzel meghatározván a módszerrel a $\pi_{t}(f(y(T)))$ árat. 
Vegyük észre, hogy ahogy a $T-2 \Delta t, T-\Delta t$ és $T$ pontokat illetően teljesül az időkonzisztencia, ha folytatjuk a módszert, és intervallumról intervallumra lépve árazunk, úgy az időkonzisztencia bármely olyan [ $t, T]$-beli pontegyüttes esetén is igaz lesz, ahol a pontok az intervallumhatárként szereplő pontok közül kerülnek ki.

Összefoglalva: ez a kis időintervallumokra történő felosztás és a hátulról előrefele történő feltételes árazás biztosítja, hogy úgy adjuk meg a kezdőpontbeli árat, hogy az intervallumhatárként szereplő köztes pontok bármely választása esetén fennálljon az időkonzisztencia feltétele. Vegyük közben észre, hogy ez az időkonzisztens árazás megadható tetszőlegesen kis $\Delta t$ időintervallum-hossz választása mellett is! Ebből adódóan persze arra is lehetőségünk kínálkozik, hogy $\Delta t \rightarrow 0$ határértékképzés mellett adjuk meg a keresett időkonzisztens árat. Ha pedig így járunk el, akkor bármely [ $t, T]$-közbülső pontok választása esetén teljesülni fog az időkonzisztencia feltétele.

Ezzel lefektettük az időkonzisztens árazás mint módszer alapjait. Konkrét szituációkban el kell döntenünk, hogy milyen árazási módszer (például szórásnégyzet elv, szórás elv stb.) mellett szeretnénk alkalmazni, továbbá feltételezéssel kell élnünk a biztosítási folyamat dinamikájával kapcsolatban is, hogy egy adott $f$ kifizetésfüggvény ismeretében pontosan megadhassuk a keresett árat.

\section{Időkonzisztens aktuáriusi értékelések}

Időkonzisztens aktuáriusi értékeléseket kaphatunk hagyományos aktuáriusi díjelvek kiterjesztésével. Ebben az írásban nem térünk ki pontosan a vonatkozó matematikai levezetésekre, csak röviden közöljük a gondolatmenet lényegét, illetve a releváns végeredményeket. Részletes levezetés és magyarázat megtalálható Antoon Pelsser és Ahmad Salahnejhad Ghalehjooghi már említett cikkében.

Mit mondhatunk el dióhéjban az időkonzisztens aktuáriusi értékelések felállításáról, melyek a szerzőpáros ötletének lényegi elemei?

A kapcsolódó biztosítási folyamatot illetően feltételezéssel kell élni, esetünkben abból indulnak ki a szerzők, hogy a folyamat az alábbi sztochasztikát követi:

$$
d y(t)=a(t, y(t)) d t+b(t, y(t)) d W(t)
$$

ahol $W(t)$ sztenderd Wiener-folyamat, $a(t, y(t))$ és $b(t, y(t))$ folytonosak és adaptáltak, továbbá $y(t)$ Itô-folyamat, négyzetesen integrálható.

A korábban is említettek értelmében az időkonzisztens ár meghatározásakor először a $[0, T]$ intervallumot kell kis időintervallumokra felosztani, és ezeken egyesével árazni, azaz egyesével kell felírni rájuk az alkalmazandó aktuáriusi elvet. (Megjegyzés: egyelöre $t$-t futóindexként fogjuk használni, így célszerűen áttértünk a 0-ra mint kezdő időpontra, ezért vizsgálódunk immár a $[0, T]$ intervallumon.)

Legyen egy ilyen kis kiválasztott intervallum a $[t, t+\Delta t]$ ! A módszer értelmében a $t$-beni árat a $t+\Delta t$-beni feltételes értékek határozzák meg (tehát a kezdőpontbeli ár a vég- pontbeli értékek függvénye), például a szórásnégyzet elv alkalmazása esetén a $t+\Delta t$-beni várható értékből és szórásnégyzetből adódik a $t$-beni ár. Ezen keresett várható érték és szórásnégyzet pedig megkapható úgy, hogy (megfelelő folytonosságokat megkövetelvén az árfüggvényre és annak deriváltjaira) felírjuk az Itô-formulát. Az Itô-formula matematikai összefüggést ír le a $t$-beni és $t+\Delta t$-beni árak között, az összefüggésből pedig kinyerhető a keresett $t+\Delta t$-beni várható érték és szórásnégyzet.

Ha a kis intervallumokon történő árazással már megvagyunk, képezhetünk $\Delta t \rightarrow 0$ határértéket. Speciálisan ez a szórásnégyzet elv alkalmazása esetén el fog minket vezetni egy parciális differenciálegyenlethez, amit a Feynman-Kac-formula segítségével tovább alakíthatunk, így eljutva annak explicit megoldásáig. Végül az alábbit kapjuk:

$$
\pi^{V}(t, y)=\frac{1}{\alpha} \ln E\left[e^{\alpha \cdot f(y(T))} \mid y(t)=y\right],
$$

ahol:

$\pi^{V}(t, y)$ : a szórásnégyzet elv alkalmazásával kapott ár $t$-ben, $(t, y)$ ismeretében $\alpha$ : a szórásnégyzet elv $\alpha$ díjelvparamétere

A fenti ár tetszőleges $0 \leq t<T$-ben megadható a biztosítási folyamat konkrét megvalósulási értéke, $y(t)$ ismeretében.

Hasonló levezetéssel kapjuk a szórás elvre:

$$
\pi^{S}(t, y)=E^{S}[f(y(T)) \mid y(t)=y]
$$

ahol:

$\pi^{S}(t, y)$ a szórás elv alkalmazásával kapott ár $t$-ben, $(t, y)$ ismeretében

$E^{s}$ : egyfajta korrigált várható érték, egészen pontosan egy módosított $y^{s}$ folyamat alapján vett várható értéket, ahol $y^{s}$ annyiban tér el $y$-tól, hogy driftje $a \pm \beta b(t, y)$ taggal egészül ki, vagyis $d y(t)=(a(t, y(t)) \pm \beta b(t, y(t))) d t+b(t, y(t)) d W(t)$

$\beta$ : a szórás elv $\beta$ díjelvparamétere

Ezzel tehát röviden, a matematikai teljesség igénye nélkül áttekintettük, hogy a feldolgozott cikk milyen konkrét eredményekre jut a szórásnégyzet elv, illetve a szórás elv időkonzisztens kiterjesztésével kapcsolatban. Az eredmények példán történő illusztrálására a cikk második felében kerül majd sor, amikor a piackonzisztencia fogalmának bevezetésével olyan értékelésekkel tudunk majd foglalkozni, melyek egyszerre lesznek piac- és időkonzisztensek. 


\section{Időkonzisztensek-e a statikus megközelítések?}

A bevezetendő új módszer megismertetésével egyidőben felvetődhet bennünk a kérdés: a korábban alkalmazott statikus módszerek, az aktuáriusi díjelvek „hagyományos” felírása ezek szerint nem teljesítette az időkonzisztencia feltételét? A válasz: nem feltétlenül, sőt, bizonyos speciális esetektől eltekintve rendszerint nem. A szórásnégyzet elv esetében ezt egy egyszerü példán mutatom be.

Legyen a vizsgált biztosítási folyamat a következő: $y(0)=100$, majd innen két lépésben, faszerüen ágazunk el: minden lépésben a folyamat értéke vagy 0,8-szeresére, vagy 0,6-szeresére változik, a két eset legyen megegyező valószínűségű, $p=\frac{1}{2}$. Ábrán szemléltetve ( $W$ a „világállapot” megjelölése, $y$ a biztosítási folyamat konkrét értéke):

1. ábra: Példa a statikus megközelítések időkonzisztenciájának megcáfolására - I.

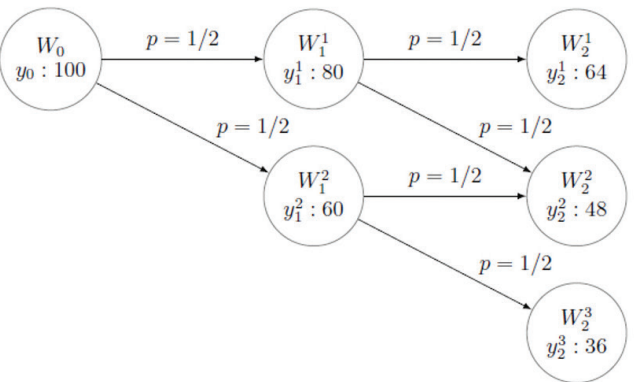

Forrás: saját szerkesztés

Ez egy lehetséges megbúvó biztosítási folyamat leképzése: 100 fős állományból indulunk, mely a következő időpontban 80, illetve 60 fösre csappanhat, majd a második időpontban már csak 64, 48, illetve 36 fös lehet. Elérési biztosítással foglalkozunk, vagyis a biztosító kizárólag a túlélőknek tartozik kifizetéssel, azaz jelen esetben a tartam végén életben maradt 64, 48, illetve 36 fönek. Az egyszerüség kedvéért tegyük fel, hogy minden túlélő egységnyi kifizetésre jogosult: $f(y(T))=1 \cdot y(T)=y(T)$, továbbá a diszkontálástól is tekintsünk el!

Most tehát szórásnégyzet elvvel árazunk. Ha a statikus árazás maga időkonzisztens lenne, akkor ugyanazt az árat szolgáltatná „egyből árazva”, mint köztes osztópontokat véve és azokon keresztül árazva. Vegyünk egyetlen köztes osztópontot, és vessük össze, hogy mit kapnánk, ha először hagyományosan, statikusan áraznánk, majd másodjára egy osztóponttal, két lépésben. (Megjegyzés I.: alsó indexben az időtényezőt fogjuk feltüntetni, amelyre vonatkozóan számítjuk a megfelelő feltételes várható értéket és szórásnégyzetet. Megjegyzés II.: az $\alpha$ díjparaméterre vonatkozóan értékadással kell élnünk. Legyen $\alpha=0,2$, sígy $\frac{1}{2} \cdot \alpha=0,1$.)
Statikus árazással:

$\pi_{0}(f(y(2)))=E_{0}(f(y(2)))+\frac{1}{2} \cdot \alpha \cdot D^{2}(f(y(2)))=$

$=\frac{1}{4} \cdot(64+48+48+36)+0,1 \cdot\left(\frac{1}{4} \cdot\left(64^{2}+48^{2}+48^{2}+36^{2}\right)-\left(\frac{1}{4} \cdot(64+48+48+36)\right)^{2}\right)=$

$=\frac{1}{4} \cdot 196+0,1 \cdot\left(\frac{1}{4} \cdot 10000-\left(\frac{1}{4} \cdot 196\right)^{2}\right)=49+0,1 \cdot 99=49+9,9=\underline{58,9}$.

- Osztópontos árazás: elsőképp az 1-es időpillanat két lehetségesen bekövetkező világállapotára vonatkozó $\pi 1$ árakat kell meghatároznunk.

- $W_{1}^{1}-r e: \pi_{1}(f(y(2)))=E_{1}\left(f(y(2)) \mid y(1)=y_{1}^{1}\right)+\frac{1}{2} \cdot \alpha \cdot D^{2}\left(f(y(2)) \mid y(1)=y_{1}^{1}\right)$ $==\frac{1}{2} \cdot(64+48)+0,1 \cdot\left(\frac{1}{2} \cdot\left(64^{2}+48^{2}\right)-\left(\frac{1}{2} \cdot(64+48)\right)^{2}\right)=\frac{1}{2} \cdot 112+0,1$.

$\left(\frac{1}{2} \cdot 6400-\left(\frac{1}{2} \cdot 112\right)^{2}\right)=56+0,1 \cdot 64=\underline{62,4}$

- $W_{1}^{2}-r e: \pi_{1}(f(y(2)))=E_{1}\left(f(y(2)) \mid y(I)=y_{1}^{2}\right)+\frac{1}{2} \cdot \alpha \cdot D^{2}\left(f(y(2)) \mid y(I)=y_{1}^{2}\right)$ $==\frac{1}{2} \cdot(48+36)+0,1 \cdot\left(\frac{1}{2} \cdot\left(48^{2}+36^{2}\right)-\left(\frac{1}{2} \cdot(48+36)\right)^{2}\right)=\frac{1}{2} \cdot 84+0,1$. $\left(\frac{1}{2} \cdot 3600-\left(\frac{1}{2} \cdot 84\right)^{2}\right)=42+0,1 \cdot 36=\underline{45,6}$.

Ezen kettő ismeretében a 0. időpontra vonatkozó ár is megadható, ábránk a következőre módosul:

2. ábra: Példa a statikus megközelítések időkonzisztenciájának megcáfolására - II.

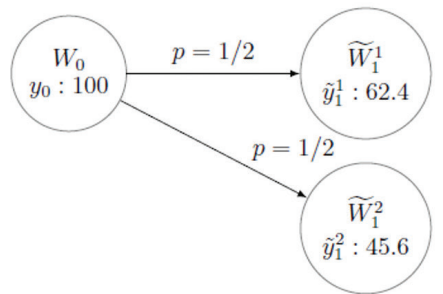

Forrás: saját szerkesztés

- $W_{0}-r a: \pi_{0}(f(y(2)))=E^{\prime}(f(y(1)))+\frac{1}{2} \cdot \alpha \cdot D^{\prime 2}(f(y(2)))=\frac{1}{2} \cdot(62,4+45,6)+$ $+0,1 \cdot\left(\frac{1}{2} \cdot\left(62,4^{2}+45,6^{2}\right)-\left(\frac{1}{2} \cdot(62,4+45,6)\right)^{2}\right)=\frac{1}{2} \cdot 108+0,1 \cdot\left(\frac{1}{2} \cdot 5973,12-\right.$ $\left.-\left(\frac{1}{2} \cdot 108\right)^{2}\right)=54+0,1 \cdot 70,56=54+7,056=\underline{61,056}$ 
Ezzel az osztópontos, kétlépéses esetre is meghatároztuk a keresett árat. Vessük is össze a statikus módszerrel kapottal!

\begin{tabular}{c|c} 
& A módszer szerinti ár 0-ban: \\
\hline Statikus árazás & 58,9 \\
\hline Osztópontos árazás & 61,056
\end{tabular}

Látható, hogy a két ár nem esik egybe.

Ezzel sikerült egy konkrét példát mutatnunk, mely alátámasztja, hogy a hagyományos, statikus árazási módszerre nem feltétlenül teljesül az időkonzisztencia követelménye.

Az időkonzisztenciáról szóló alfejezeteket röviden összefoglalva: példa bemutatásával illusztráltuk, hogy a hagyományos aktuáriusi díjelvekre nem feltétlenül igaz az, hogy egy időhorizonton kiértékelve ugyanazt az árat kérnénk, mintha az adott időhorizontot intervallumokra osztanánk, és azokon keresztül pontról pontra értékelnénk.

\section{A hagyományos, statikus árazási módszerre nem feltétlenüil teljesül}

\section{az időkonzisztencia követelménye.}

Mindazonáltal ez egy természetesen felvetődő igény lehet biztosítási termékek árazásakor. Az időkonzisztencia feltételének megkövetelése hívta életre a már bevett aktuáriusi díjelvek időkonzisztens kiterjesztésének ötletét. Antoon Pelsser és Ahmad Salahnejhad Ghalehjooghi Time-Consistent Actuarial Valuations címü 2015-ös cikkének feldolgozásával áttekintettük, hogy milyen konkrét eredmények adódnak a szórásnégyzet elv, valamint a szórás elv időkonzisztens felírásából.

\section{A piackonzisztenciáról általában}

Az időkonzisztencia fogalmának bevezetését követően áttérhetünk a piackonzisztencia fogalmára. A végcélunk az, hogy az általunk használt értékelések immáron ne csak az időkonzisztencia feltételét teljesítsék, hanem a piackonzisztenciáét is. Ezt úgy fogjuk elérni, hogy a már széles körben ismert aktuáriusi díjelveket nemcsak időkonzisztens irányba fogjuk kiterjeszteni, hanem piackonzisztens irányba is. Mindenekelőtt azonban meg kell értenünk, hogy mit is értünk a piackonzisztencia fogalma alatt, illetve mi indokolhatja, hogy azt megköveteljük biztosítási termékeink árazásakor.

Ahogy már korábban említettük, a biztosítási piacon már régóta nagy számban vannak jelen olyan termékek, amelyek kockázata nem pusztán egy kapcsolódó biztosítási folyamat véletlenségéből fakad, hanem pénzügyi, piaci kockázatot is magukban foglalnak. Ilyenek akár a részvényárfolyamokon alapuló termékek (például a unit-linked biztosítások), akár a garanciális kifizetések.
Amikor az aktuáriusi és pénzügyi kockázat különbözőségéről beszélünk, nem csupán azért tesszük, mert más a kockázat forrása, de maga a kockázati jelleg is eltérő lesz. Míg az előbbit hedzselni rendszerint nem tudjuk, addig az utóbbit sok esetben igen. Ez azt jelenti, hogy annak ellenére, hogy biztosítóként egy véletlen kifizetést vállalunk el, nem feltétlenül vagyunk kiszolgáltatva annak kockázatával szemben. Egy leegyszerüsített példa: ha azt vállaljuk, hogy tíz év múlva kifizetjük egy adott részvény akkori árát, akkor hiába követ az ár véletlen folyamatot, ha most megvesszük a részvényt, és tíz évig tartjuk, akkor tíz év múlva lényegében rendelkezésünkre fog állni az akkori ára, azaz megfelelő hedzseléssel (most: a részvény megvásárlásával) elérhetjük, hogy a részvényár változása okozta kockázattal szemben semlegesek legyünk. Ennél egy fokkal összetettebb példa lehetne, ha nem azt vállaljuk, hogy kifizetjük tíz év múlva a részvény árát, hanem azt, hogy elérési biztosítással kombináljuk, vagyis amennyiben a biztosított megéli a tizedik évet, úgy jogosult lesz az akkori részvényár-kifizetésre, különben viszont nem. Az utóbbi példa továbbfejlesztése, illetve átdolgozása vezet el a unit-linked biztosítási termékekhez, amelyek jelenleg is meghatározó részét képezik az életbiztosítási piacnak. Érezhető, hogy milyen fontos feladat így a piaci, pénzügyi kockázatok biztosítói értékelése.

A piackonzisztencia azt követeli meg, hogy azoknak az instrumentumoknak az ára, melyek replikálhatóak, egyezzen meg a replikálási árral.

Röviden azt mondhatjuk, hogy a piackonzisztencia azt követeli meg, hogy azoknak az instrumentumoknak az ára, melyek replikálhatóak, egyezzen meg a replikálási árral.

Tehát ha egy terméket elő tudunk állítani egyéb, piacon fellelhető termékek kombinációjaként, akkor azt azokkal összhangban, azokkal konzisztensen árazzuk. Hogyan valósítható ez meg egy biztosító keretrendszerében?

\section{Piackonzisztencia a biztosításban}

A piackonzisztenciát és annak biztosítási szektorban való megjelenését mélyrehatóan feldolgozta a Mario Valentin Wüthrich, Hans Bühlmann és Hansjörg Furrer szerzőhármas által írt Market-Consistent Actuarial Valuation című könyv. Ebben kifejtésre kerül több, a témához kapcsolódó elméleti és gyakorlati megfontolás is, mindazonáltal a mü részletes ismertetésére ennek a cikknek a keretében nem nyílik lehetőségünk. Egyetlen, témánkhoz szorosan füződő szeletét fogjuk áttekinteni: a kiértékelési portfólió mibenlétét, illetve felírását determinisztikus modellben. Ezután röviden utalunk a sztochasztikus modellbe való átültetésére is. Ezen elméleti alapokat azért is fektetjük le, hogy a későbbiekben rátérhessünk az írás kulcstémájára, és felállíthassunk olyan aktuáriusi értékeléseket, melyek már egyszerre lesznek idő- és piackonzisztensek. 


\section{Kiértékelési portfólió}

A kiértékelési portfólióról szóló alfejezetek az előbb említett könyvben olvasottak értelmezésével készültek. A piackonzisztencia megvalósításának alapja egy ún. kiértékelési portfólió felállítása. $\boldsymbol{X}$-szel jelölvén a biztosítási portfóliót az $X \rightarrow \operatorname{VaPo}(\boldsymbol{X})$ hozzárendelést keressük, ahol a VaPo jelölés a valuation portfólióra, azaz a kiértékelési portfólióra utal.

A biztosítási portfóliónk értékelésekor elsőként a piacon kereskedett termékek összességeként írjuk fel, végül ez utóbbinak kell majd meghatároznunk az árát. Lényegében arra törekszünk, hogy az eredeti biztosítási portfóliónkat egy replikáló portfólióvá alakítsuk át, ahol a replikáló portfólió már meghatározott pénzügyi termékekből tevődik össze.

A replikálás és értékelés két fázisban történik. Először feltesszük, hogy a halálozási tábla determinisztikus, vagyis nincsen aktuáriusi kockázat, pontosan ismert, hogy mikor hányan haláloznak el. A második lépésben pedig már számolnunk kell az aktuáriusi kockázattal is, vagyis a korábbi kiindulásként használt determinisztikus tábla helyett sztochasztikus táblára kell áttérnünk. A determinisztikus táblával történő operálást részletesen kifejtjük, hogy világossá váljon a kiértékelési portfólió felállításának elmélete, a sztochasztikus megfontolással kevesebbet időzünk, annak csak lényegesebb gondolati elemeit emeljük ki.

\section{Kiértékelési portfólió, determinisztikus modell}

A könnyebb érthetőség kedvéért egy példán illusztrálva fogjuk levezetni a kiértékelési portfólió felállítását. Nem ugyanazt a példát vizsgáljuk, amelyet a felhasznált irodalom, attól eltérő tartammal és induló életkorral fogunk dolgozni, ugyanakkor mi is egy vegyesbiztosítást veszünk alapul, hogy az elérési és haláleseti kifizetés egyaránt bemutatható legyen. Továbbá ugyanúgy lesz garanciális kifizetésünk, hogy annak replikálását is szemléltetni tudjuk. Lássuk is a példát!

A biztosításba történő belépési kor 40 , a tartam 3 év $(x=40, n=3)$. A biztosítási díj állandó, minden év elején felmerülő: $\Pi_{t}=\Pi, t=40,41,42$. A haláleseti és elérési kifizetések egy előre megnevezett $\boldsymbol{I}$ index (vagy részvény) adott évi értékének lesznek függvényei $\left(I_{t}, t=41,42,43\right)$, ahol az induló érték egységnyi, $I_{40}=1$. A kifizetések:

- $\quad$ Elérési: $I_{43}$, garancia nélküli.

- Haláleseti $(t=41,42,43): \max \left(I_{t},(1+i)^{t-40}\right)$, ahol $i$ előre rögzített kamatláb. Ez a kifizetés tehát garanciális, évi $i$ százalék kamatgaranciát vállal.

A mortalitási tábla szokásos jelöléseivel legyen $l_{x}$ az $x$. életkort megéltek, $d_{x}$ pedig az $x$. életkort még megélt, de $x+1$.-et már nem elérők száma! (Értelemszerűen: $d_{x}=l_{x}-l_{x+1}$.) Ekkor a biztosító ki- és befizetéseit az 1. táblázatban foglaljuk össze.
1. táblázat: A biztosító determinisztikus halálozás melletti be- és kifizetése

\begin{tabular}{|c|c|c|c|c|}
\hline$t$ & cash flow & biztosítási díj & haláleseti kifizetés & elérési kifizetés \\
\hline 40 & $\mathrm{X}_{40}$ & $-1_{40} \cdot \Pi$ & & \\
\hline 41 & $\mathrm{X}_{41}$ & $-1_{41} \cdot \Pi$ & $\mathrm{d}_{40} \cdot \max \left(\mathrm{I}_{41},(1+\mathrm{i})^{1}\right)$ & \\
\hline 42 & $\mathrm{X}_{42}$ & $-1_{42} \cdot \Pi$ & $\mathrm{d}_{41} \cdot \max \left(\mathrm{I}_{42},(1+\mathrm{i})^{2}\right)$ & \\
\hline 43 & $\mathrm{X}_{43}$ & & $\mathrm{~d}_{42} \cdot \max \left(\mathrm{I}_{43},(1+\mathrm{i})^{3}\right)$ & $1_{43} \cdot \mathrm{I}_{43}$ \\
\hline
\end{tabular}

Forrás: saját szerkesztés

Keressük az ezt replikáló portfóliót, $\mathrm{VaPo}(\boldsymbol{X})$-et. Lássuk is, milyen egységekből építhetjük ezt fel!

- $\quad$ Biztosítási díj: zéró-kupon kötvényekkel: $Z_{40}, Z_{41}, Z_{42}$. A két év múlva esedékes egy egységnyi befizetés replikálható például egy most megvásárolt két év tartamú zéró-kupon kötvénnyel.

- $\quad$ Elérési kifizetés: az eléréskor esedékes $I_{43}$ kifizetés replikálható az I index (részvény) azonnali megvásárlásával.

- Haláleseti kifizetés: az előbbieknél összetettebb, a $t$ időpontra vonatkozóan $\boldsymbol{I}+P u t^{(t)}\left(\boldsymbol{I},(1+i)^{t-40}\right)$, ahol $t=41,42,43$. Az index (részvény) megvásárlása mellett tehát egy put opcióra is szükségünk van, mégpedig egy olyanra, amely lehetővé teszi, hogy $t$ időpontban az $I$ részvényünket $(1+i)^{t-40}$ áron eladhassuk. Ez leképezi a max $\left(I_{t},(1+i)^{t-40}\right)$-et: ha az ár $t$-ben $(1+i)^{t-40}$ felett van, akkor nem érvényesítjük a put opció lehetőségét, így valóban It értékkel fogunk rendelkezni, ha az ár viszont $(1+i)^{t-40}$ alá kerül, akkor az index értéke az opció értelmében $(1+i)^{t-40}$-re "cserélhetö". Összességében a $t$-beli kifizetés valóban $\max \left(I_{t},(1+i)^{t-40}\right)$ lesz.

Mindezek alapján felírható egy bázis a portfólióhoz tartozó kifizetések replikálására, mégpedig az alábbi hétdimenziós vektorral:

$\left(Z_{40}, Z_{41}, Z_{42}, \mathbf{I}, P u t^{(41)}\left(I,(1+i)^{1}\right), \quad P u t^{(42)}(I,(1+i) 2), \quad P u t^{(43)}\left(I,(1+i)^{3}\right)\right)$

A portfólió replikálásának hátramaradó lépése, hogy azt is megmondjuk, hogy az egyes báziselemekből mennyi szükségeltetik. Visszakanyarodva a korábban felírt replikálási táblázatunkhoz, a determinisztikus halálozási tábla feltételezéseivel élve ezek az értékek a 2. táblázatban olvashatók.

2. táblázat: A replikáló portfólió összetétele

\begin{tabular}{|c|c|}
\hline báziselem & egységek száma \\
\hline$Z_{40}$ & $-1_{40} \cdot \Pi$ \\
\hline$Z_{41}$ & $-1_{41} \cdot \Pi$ \\
\hline$Z_{42}$ & $-1_{42} \cdot \Pi$ \\
\hline$I$ & $\mathrm{~d}_{40}+\mathrm{d}_{41}+\mathrm{d}_{42}+\mathrm{l}_{43}=1_{40}$ \\
\hline$P u t^{(41)}\left(\mathbf{I},(1+\mathrm{i})^{1}\right)$ & $\mathrm{d}_{40}$ \\
\hline$P u t^{(42)}\left(\mathbf{I},(1+\mathrm{i})^{2}\right)$ & $\mathrm{d}_{41}$ \\
\hline$P u t^{(43)}\left(\mathbf{I},(1+\mathrm{i})^{3}\right)$ & $\mathrm{d}_{42}$ \\
\hline
\end{tabular}

Forrás: saját szerkesztés 
Sikeresen replikáltuk tehát a biztosítási portfóliónkat: először meghatároztunk egy bázist, majd felírtuk a portfóliónkat ebben a bázisban, így megadtuk a replikáló vektorunkat. Innentől a kiértékelés úgy történik, hogy egy kiértékelési függvény segítségével árat rendelünk ehhez a replikáló vektorhoz. Feltételezvén, hogy ismertek az egyes báziselemek árai (vagyis ismertek a megfelelő zéró-kupon kötvények, az index, illetve a megfelelő put opciók árai), már a replikáló portfólió ára is meghatározható: valamennyi báziselemből a replikáláshoz szükséges mennyiséget véve a portfólió ára ezen árak összegeként fog adódni. Matematikailag: először az $\boldsymbol{X} \rightarrow \operatorname{VaPo}(\boldsymbol{X})$ hozzárendelést elvégezve felírhattuk a portfóliónk replikálását, majd ezután egy $A$ kiértékelési lineáris funkcionált véve ezen elvégezhetjük a $\mathrm{VaPo}(\boldsymbol{X}) \rightarrow A(\mathrm{VaPo}(\boldsymbol{X}))$ hozzárendelést, amely tehát már értéket rendel a replikáló portfólióhoz.

Megjegyzés: érdemes azonban szót ejteni arról is, hogy ez a kiértékelési $A$ függvény nem feltétlenül áll a rendelkezésünkre, például nem szükségszerűen kereskednek a piacon hétéves zéró-kupon kötvényekkel, noha lehet az az egyik báziselemünk. Így előfordulhat, hogy egyéb megfontolásokra és módszerekre is szükségünk van a portfólió árának meghatározásához. Ebből az észrevételből adódóan persze az is elmondható, hogy a kiértékelési függvényünk nem is feltétlen egyértelmű. A hétéves zéró-kupon kötvény példájánál maradva: ha nincs adott ára egy báziselemnek, akkor az azt értékelő különböző hozzáállások is eltérő értékeket rendel(het)nek hozzá, így végeredményben eltérő kiértékelési függvényt eredményez(het)nek.

\section{Kiértékelési portfólió, sztochasztikus modell}

A piackonzisztens értékelés második fázisa már sztochasztikus halálozási táblával dolgozik. Az első fázisban determinisztikus táblát vettünk alapul, tehát lényegében nem foglalkoztunk az aktuáriusi kockázattal, amit egy kapcsolódó biztosítási folyamat (például a túlélésszám) sztochasztikája okozott. Ebben a fázisban viszont már ez a kockázat is számításba vehető azáltal, hogy a modellünk most már sztochasztikus mortalitási táblára fog építeni.

Miből fakad egyáltalán a kockázat? Abból, hogy a halálozások immár nem determinisztikusak, így a hozzájuk kapcsolódó pénzáramok sem lesznek azok. Ebben a fázisban úgy fogunk egy portfóliót felírni, hogy annak alapja az előző fázisban bevezetett replikáló portfólió legyen: a mortalitási tábla legjobb becslése determinisztikus táblát ad, és ez alapján felépíthető az előző fázisban tárgyalt replikáló portfólió. Ugyanakkor a most jelen levő véletlenség miatt ezt a portfóliót kiegészíteni kényszerülünk egyfajta plusz biztonságot adó kockázati ráhagyással.

A determinisztikus modellhez hasonlóan most is egy példán szemléltetjük a módszert. Akárcsak az első fázisban, a feladatunk ismét egy kiértékelési portfólió felállítása lesz. A vizsgálat alapjául szolgáló biztosítás legyen ugyanaz, mint a korábban látott: a vegyesbiztosítás paraméterei mind megegyezőek az előbb látottakkal, az egyedüli eltérés az lesz, hogy most miután elindultunk az $l_{40}$ életben lévővel, már engedjük a túlélési folyamatot sztochasztikusan továbbfejlődni. (Î́gy térünk át determinisztikusról a sztochasztikus mortalitási táblára.) A következő években tehát a túlélések véletlenszámok lesznek: $L_{41}, L_{42}, L_{43}$, illetve hasonlóan a halálozási számok is: $D_{40}, D_{41}, D_{42}$.

Ezeket figyelembe véve a második fázis ki- és befizetései az alábbiak (3. táblázat).

3. táblázat: A biztosító sztochasztikus halálozás melletti be- és kifizetései

\begin{tabular}{|c|c|c|c|c|}
\hline $\mathrm{t}$ & cash flow & biztosítási dij & haláleseti kifizetés & elérési kifizetés \\
\hline 40 & $\mathrm{X}^{*}{ }_{40}=\mathrm{X}_{40}$ & $-\mathrm{-}_{40} \cdot \Pi$ & & \\
\hline 41 & $\mathrm{X}^{*}{ }_{41}$ & $-\mathrm{L}_{41} \cdot \Pi$ & $\mathrm{D}_{40} \cdot \max \left(\mathrm{I}_{41},(1+\mathrm{i})^{1}\right)$ & \\
\hline 42 & $\mathrm{X}^{*}{ }_{42}$ & $-\mathrm{L}_{42} \cdot \Pi$ & $\mathrm{D}_{41} \cdot \max \left(\mathrm{I}_{42},(1+\mathrm{i})^{2}\right)$ & \\
\hline 43 & $\mathrm{X}^{*}{ }_{43}$ & & $\mathrm{D}_{42} \cdot \max \left(\mathrm{I}_{43},(1+\mathrm{i})^{3}\right)$ & $\mathrm{L}_{43} \cdot \mathrm{I}_{43}$ \\
\hline
\end{tabular}

Felírható a replikáló vektor is a már korábban felállított bázisban (4. táblázat).

4. táblázat: A replikáló portfólió összetétele sztochasztikus halálozás mellett

\begin{tabular}{|c|c|}
\hline báziselem & egységek száma \\
\hline $\mathrm{Z}_{40}$ & $-1_{40} \cdot \Pi$ \\
\hline $\mathrm{Z}_{41}$ & $-\mathrm{L}_{41} \cdot \Pi$ \\
\hline $\mathrm{Z}_{42}$ & $-\mathrm{L}_{42} \cdot \Pi$ \\
\hline $\mathbf{I}$ & $\mathrm{D}_{40}+\mathrm{D}_{41}+\mathrm{D}_{42}+\mathrm{L}_{43}=\mathrm{I}_{40}$ \\
\hline$P u t^{(41)}\left(\mathbf{I},(1+\mathrm{i})^{1}\right)$ & $\mathrm{D}_{40}$ \\
\hline$P u t^{(42)}\left(\mathbf{I},(1+\mathrm{i})^{2}\right)$ & $\mathrm{D}_{41}$ \\
\hline$P u t^{(43)}\left(\mathbf{I},(1+\mathrm{i})^{3}\right)$ & $\mathrm{D}_{42}$ \\
\hline
\end{tabular}

Forrás: saját szerkesztés

Látjuk, hogy most már a replikáló vektorunk elemei között véletlenszámok is megjelennek. Nyilván ezzel önmagában nem haladhatunk tovább, elvégre nem replikálhatunk véletlen mennyiségekkel. Ugyanakkor felírhatjuk, hogy milyen eltérés mutatkozik a mostani és az előző fázisbeli pénzáramok (és így a replikáló vektorok) között, vagyis megpróbálhatjuk valamelyest a mostani esetünket visszavezetni az 1. és 2. táblázat szerint korábban tárgyaltra.

Mik is pontosan ezek a pénzárambeli eltérések? Îrjuk fel a bázis alapján! Tegyük meg ezt $t=41$-re, hiszen ez az első év, ahol különbség mutatkozik a pénzáramok között! Az eltérések:

- A biztosítási díjból fakadóan: $\left(l_{41}-L_{41}\right) \cdot \Pi \cdot Z_{41}$.

- A haláleseti kifizetésből fakadóan: $\left(D_{40}-d_{40}\right) \cdot\left(\boldsymbol{I}+P u t^{(41)}\left(\boldsymbol{I},(1+i)^{1}\right)\right)$.

- Ezen felül értelemszerüen a $t=41$-ben történő változás a későbbi évekre tartott portfóliót is felülírja, ezen portfólió megváltozását is meg kell adnunk. A t=42-re vonatkozó kiértékelési portfóliót $\operatorname{VaPo}\left(\boldsymbol{X}_{42}\right)$-vel jelölve ez a differencia:

$$
\left(L_{41}-l_{41}\right) \cdot \frac{\operatorname{VaPo}(X 42)}{I^{41}}
$$


Hasonló elgondolással adhatók meg a következő évekre vonatkozó eltérések is. Ezen eltérések meghatározzák a kockázatnak kitett portfóliót minden egyes év esetében, ami alapján a biztosító kockázati többletet állapíthat meg. A kockázati többletért elkért felár természetesen függ a biztosító kiértékelésétől. A kérdés, hogy a véletlen eltérésért hogyan felárazunk, már az aktuáriusi díjelveknél is előkerült. Ez alapvetően függhet attól, hogy a kapcsolódó biztosítási folyamat miféle sztochasztikát követ. A szórásnégyzet, illetve szórás elvek a megkövetelt felárat például a folyamat szórásnégyzetével, illetve szórásával arányosították.

Mire jutottunk, hogyan valósítható meg a piackonzisztencia egy biztosítási portfólió esetében? Elsőképp a vonatkozó determinisztikus tábla szerint kell felállítanunk a replikáló portfóliót $(\mathrm{VaPo}(\boldsymbol{X}))$, amelyhez egy kiértékelési funkcionál ( $A$ függvény) segítségével ár rendelhető. Ezt követően meghatározandóak a különböző évekre vonatkozó kockázati portfóliók, amelyek ugyancsak beárazhatók a biztosító által használt kiértékelés segítségével.

\section{Piac- és időkonzisztens aktuáriusi értékelések}

Mindkét fogalom tisztázását követően lehetőségünk nyílik arra, hogy ötvözzük a kettőt, vagyis immár olyan értékelésekkel foglalkozzunk, amelyek egyszerre idő- és piackonzisztensek. Mi hívja életre az elvárást, hogy egy értékelés egyaránt teljesítse a két követelményt?

Ahogy arról már szó esett, manapság sok olyan termék fordul elő a biztosítási piacon, amely aktuáriusi és pénzügyi kockázatot egyaránt magában foglal, és mi szeretnénk egy olyan eszközt a kezünkben, amely kezelni tudja ezt a kockázatkettőst.

A pénzügyi termékek árazásánál már hozzászokhattunk ahhoz, hogy egyfajta dinamikus környezetben értékelünk, vagyis a pénzügyi folyamat fejlődésdinamikájának leképezése mellett. Ez a dinamikus környezet maga után vonja az időkonzisztenciát, elvégre a pénzügyi termékek árazásakor természetesen adódik, hogy az ár ugyanaz, ha „egyből értékelünk”, mintha az időhorizontot felosztva értékelnénk pontról pontra. Adódik tehát az ötlet, hogy a biztosítási termékekre is vigyük át ezt a fajta dinamikus, időkonzisztens logikát, terjesszük ki a már ismert aktuáriusi díjelveket időkonzisztens módon. Ha pedig ez megvan, úgy a piackonzisztencia feltétele is könnyen átültethetővé válik, vagyis végeredményben olyan értékeléseknél kötünk ki, amelyek egyaránt időés piackonzisztensek, és így alkalmasak lesznek az aktuáriusi és pénzügyi kockázatok együttes kezelésére.

Antoon Pelsser és Mitja Stadje 2014-ben megjelent Time-Consistent and Market-Consistent Evaluations című cikkében foglalkozik a kétféle konzisztencia vegyítésével, együttes megkövetelésével. Az aktuáriusi díjelvek kétirányú kiterjesztése kézenfekvő lehetőséget ad idő- és piackonzisztens értékelések felállítására. A cikk egyik fontos eredménye, hogy formalizálja a mindkétféle konzisztenciával rendelkező értékeléseket. Ehhez elsőképp definiálja az úgynevezett kétlépcsős piaci értékeléseket, majd belátja, hogy megfelelő követelmények teljesülése esetén az idő- és piackonzisztens értékelések egybeesnek a kétlépcsős piaci értékelésekkel.

A cikk átfogó bemutatására most nem kerül sor, mindössze arra szorítkozunk, hogy egy kiemelkedően fontos következtetését közöljük. Legtöbbször olyanok az aktuáriusi és pénzügyi kockázatot egyaránt tartalmazó szerződéseink, hogy a két kockázat egymástól függetlenül jelenik meg. Az aktuáriusi kockázat a leendő kifizetések számával kapcsolatban merül fel, a pénzügyi pedig egyetlen konkrét kifizetés nagyságára vonatkozóan, és ezek egymástól függetlenek. Ilyenkor a kifizetés maga is szorzatalakban írható fel: $y_{T} \cdot f\left(S_{T}\right)$, ahol $y_{T}$ az $y$ biztosítási folyamat $T$-ben felvett értéke (például a túlélők száma), ennyiszer köteles kifizetni a biztosító a szóban forgó pénzügyi instrumentumot, $f\left(S_{T}\right)$ pedig egy darab kifizetendő pénzügyi instrumentum $T$-beli értéke. Ekkor a cikk eredményének megfelelően a kétlépcsős értékelés formulája alapján a portfólió értékelése meg fog egyezni $y_{T}$ kiértékelési értékének és az $f\left(S_{T}\right)$ replikálási értékének szorzatával.

\section{Az aktuáriusi és pénzügyi kockázat egymástól függetlenül jelenik meg.}

Nézzünk is meg egy egyszerű példát a könnyebb megérthetőség kedvéért! Vállalja azt a biztosító, hogy az állomány túlélőinek (meghatározott tartam mellett) fizeti egyenként elérési kifizetésként $1000 \boldsymbol{R}$ részvény árát! Ekkor egyrészt áraznia kell a szóban forgó pénzügyi instrumentumo(ka)t, jelen esetben egy före az $1000 \boldsymbol{R}$ részvényt, ami most replikálás okán értelemszerűen megegyezik az $1000 R$ részvény aktuális árával. Másrészt szükséges kiértékelnie $y_{T}$-t: ez egy előre megválasztott technika alapján történik, például a szórásnégyzet vagy szórás elv időkonzisztens kiterjesztése szerint. A portfólió értékelése meg fog egyezni ezen két értéknek (tehát $f\left(S_{T}\right)$ replikálási értékének és $y_{T}$ kiértékelési értékének) a szorzatával.

\section{Elméleti eredményeink alkalmazása}

Alkalmazzuk elméleti eredményeinket! Két konkrét példát nézünk most meg, hogy láthassuk, a bevezetett módszer miképp alkalmazható a gyakorlatban biztosítási szerződések árazására. (A példák hangsúlyozottan egyszerűsített példák lesznek, és a kifizetések nagyságrendje sem felel meg a valóságnak, mindazonáltal ezek alkalmasak arra, hogy rajtuk a módszer szemléltethető legyen.) Az előre kiválasztott technika, mellyel a biztosítási folyamatok kockázatát fogjuk értékelni, legyen a szórás elv, a kapcsolódó biztosítási folyamatok pedig kövessenek geometriai Brown-mozgást. Természetesen más elvvel is értékelhetnénk, és a biztosítási folyamatok is lehetnének eltérő dinamikájúak, de most elsősorban a kétlépcsős piaci értékelés mint módszer bemutatása a cél, ehhez 
pedig elegendő ezek tanulmányozása. Más elv, illetve más dinamika választásával a képleteink értelemszerüen módosulni fognak.

A biztosítási folyamat geometriai Brown-mozgás, tehát az alábbi alakú: $d y(t)=a \cdot y(t) d t+b \cdot y(t) d W(t)$

speciálisan legyen $y(0)=10000$, illetve $a=-0,02, b=0,015$, vagyis: $d y(t)=-0,02 \cdot y(t) d t+0,0015 \cdot y(t) d W(t)$

A szórás elv díjparaméterének $\beta=0,2$-t választjuk. Ezekben a példákban 0 a kezdő időpontunk, erre vonatkozóan fogunk értékelni.

Első példa: Az előzőben felvázolt példához hasonlóan vállalja a biztosító, hogy elérési kifizetésként 10 éves tartam ( $T=10)$ mellett minden túlélőnek 1000 I index árát téríti (I tetszőleges index). Ekkor a korábbi összefüggés alapján a biztosító által meghatározott portfólióérték az y biztosítási folyamat kiértékelésének és az 1000 I replikálási értékének szorzatával fog megegyezni.

- Az időkonzisztens árazás alapján y szórás elvvel történő kiértékelése: $\pi^{S}(0, y)=E^{S}[y(10) \mid y(0)=10000]$,

ahol $E^{S}$ a módosított $y$-folyamat szerinti várható értéket jelöli, vagyis azt, amelynél: $d y(t)=(a(t, y(t)) \pm \beta b(t, y(t))) d t+b(t, y(t)) d W(t)$

(Esetünkben egy derivált vizsgálatából következik, hogy a megjelenő előjel + lesz. Részletes magyarázatra most nem térünk ki.) Ebből: $E^{S}[y(10) \mid y(0)=10000]=$

$=y_{0} e^{(a+\beta b) \cdot 10}=10000 \cdot e^{(-0,02+0,2 \cdot 0,015) \cdot 10} \approx 10000 \cdot 0,8437=8437$.

- Az $1000 I$ index kiértékelése (legyen a 0 -beni ár $c_{I}$ ): $1000 \cdot c_{I}$.

Az egész portfólió kiértékelése ezek szorzata: $8437 \cdot 1000 \cdot c_{I}$

Láthatjuk, hogy a biztosító úgy kezelte a portfóliót, mintha 8437 életben maradóval kalkulálna, melyek mindegyikének $1000 \cdot c_{I}$ kifizetéssel tartozna. Valójában a túlélők várható értéke nem 8437 , hanem $10000 \cdot e^{-0,02 \cdot 10} \approx 10000 \cdot 0,8187=8187$. A két érték különbözete a szórás elv időkonzisztens kiterjesztése által adott kockázati ráhagyásból adódik. Ennek gyakorlati jelentősége, hogy a biztosító hedzseléskor nem 8187 före vásárolhat meg egyenként $1000 \mathrm{db}$ I indexet, hanem a kockázat menedzselése érdekében 8437 före.

Második példa: Az első példa kiegészítéseként a biztosító azt vállalja, hogy elérési kifizetésként 10 éves tartam $(T=10)$ mellett minden túlélőnek $1000 I$ index árát fizeti, most azonban ráadásul hozamgaranciát is vállal, évi $i$ százalékot. Minden egyéb feltevésünk megegyezik az első példában látottal. Mennyire értékeli a biztosító ezt a portfóliót?

Most $f\left(S_{10}\right)=1000 \cdot \max \left(I_{10},(1+i)^{10}\right)$. Ennek replikálása: $1000 \cdot\left(I+P u t^{(10)}\left(I,(1+i)^{10}\right)\right)$. $I$ index ára 0 -ban $c_{I}$, a rá vonatkozó put opcióé pedig $p_{t(1+i j)^{10}}^{10}$. Ekkor egy darab instrumentum értékelése $c_{I}+p_{I,(1+i)^{10}}^{10}$ lesz, így 1000 -é: $1000 \cdot\left(c_{I}+p_{1,(1+i)^{10}}^{10}\right)$.

Innen az egész portfólió kiértékelése ( $y$-t már kiértékeltük az előző példában a szórás elv időkonzisztens kiterjesztése alapján): $8437 \cdot 1000 \cdot\left(c_{I}+p_{I(1+i) 10}^{10}\right)$.
Ezzel két egyszerű példán keresztül illusztráltuk, hogy miképpen alkalmazandó a bevezetett módszertan. Még egyszer: az együttesen megjelenő aktuáriusi és pénzügyi kockázatok fair értékelését kívántuk lehetővé tenni aktuáriusi díjelvek piac- és időkonzisztens kiterjesztésével. A vonatkozó irodalom mélyreható feldolgozása itt nem történt meg, csupán egy kiemelkedően fontos eredményével foglalkoztunk, miszerint abban a speciális esetben, mikor a kétféle kockázattípus egymástól függetlenül jelenik meg, úgy a portfólió értékelése jelentősen leegyszerűsödik, $f\left(S_{T}\right)$ replikálási értékének és $y_{T}$ kiértékelési értékének szorzataként fog adódni. Két példa megoldásán keresztül mutattuk be, hogy ez a gyakorlatban milyen formát ölthet.

\section{Köztes időpontok a piac- és időkonzisztens aktuáriusi értékelésekben}

Az előzőekben bevezettük, hogy mit értünk piac- és időkonzisztens aktuáriusi értékelések alatt. Ezek az értékelések már alkalmasak arra, hogy egy biztosítási portfólióban megjelenő aktuáriusi és pénzügyi kockázatot együttesen kezeljenek. Milyen egyéb előnyös tulajdonsággal rendelkeznek emellett?

Vegyük észre, hogy ezek a kiértékelések nem pusztán 0-ban adnak értéket, hanem tetszöleges belső helyen felírhatóak, ahol rendelkezünk információval (például olyan pontokban, ahol a biztositási folyamat aktuális értéke ismertté válik): a $t \in[0, T]$ értékelésnél $t$-re vonatkozó feltételt véve kell áraznunk.

A portfólió tehát a biztosítási folyamatot követve újraértékelhető köztes pontokban, az újonnan rendelkezésre álló információk ismeretében. Első példánknál maradva tegyük fel, hogy a biztosító a már felírt sztochasztikus folyamatból indult ki. Az első év végén ismertté válik a túlélésszám, ami 9900. A biztosító előzetes feltevése alapján ezzel szemben $10000 \cdot e^{-0,02 \cdot 1} \approx \approx 10000 \cdot 0,9802=9802$ várható túlélővel számolt. Mit tehet ekkor? Ujraértékelheti a portfóliót $t=1$-re vonatkozó feltételes értékeket véve (a korábban megjelent $E^{S}[y(10) \mid y(0)=10000]$ szorzót $E_{1}^{S}[y(10) \mid y(1)=9900]$-re cserélvén).

Ezen újrakalkulálásnak gyakorlati jelentősége is van. Nyomatékosítanunk kell, hogy a bevezetett piac- és időkonzisztens értékelések módszere már erősen épít a hedzselés elvére. A kifizetés replikálásának felírása megfelel annak, mintha induláskor lefedeznénk portfóliónkat. Az első példánkból kiindulva a kiértékelés megfelel annak, mintha induláskor megvásárolnánk 8437 före egyenként $1000 \mathrm{db} I$ indexet. Mi történik $t=1$-ben? Módosul(hat) nak a várakozásaink, és ez a gondolat gyakorlati jelentőséggel is bír. Amennyiben már más túlélőszámmal kell kalkulálnunk, úgy hedzselési stratégiánkat is ahhoz kell igazítanunk. Esetünkben: $t=0$-ban $E^{S}[y(10) \mid y(0)=10000]$-re kalkulálva írtuk fel árazásunk, $t=1$-ben viszont már $E^{S}[y(10) \mid y(1)=9900]$-re. A különbözetnek megfelelő mennyiségben tehát $\boldsymbol{I}$ indexet kell tartanunk, hogy a $t=1$-beli értékelésünkkel összhangban maradjunk.

Ebből az is következik, hogy az idő- és piackonzisztens értékelések lehetőséget tudnak biztosítani arra, hogy a biztosító a $[0, T]$ intervallum belső pontjaiban is reagálhasson a kap- 
csolódó biztosítási folyamat alakulására. Ha például valamely köztes időpontban azt tapasztalja, hogy jóval több túlélőre számíthat, mint azt az elözetes számításai implikálták, akkor annak megfelelően tudja igazítani replikáló portfólióját.

\section{Utószó, összefoglalás}

Írásom célja az volt, hogy betekintést adjak, miképp lehet olyan értékeléseket felállítani, melyek fair módon képesek értékelni biztosítási kötelezettségeket, így az azokban felmerülő aktuáriusi és pénzügyi kockázatot tudják együttesen kezelni. Egy lehetséges értékelési módszert nyerhettünk a hagyományos aktuáriusi díjelvek idő- és piackonzisztens kiterjesztéséből. A kiterjesztést előbb időkonzisztens, majd piackonzisztens módon alkalmaztuk, eközben megismerkedtünk mindkétfajta konzisztencia jelentésével. Végül a kettőt összefogva már olyan értékeléseket lehetett formalizálni, melyek mindkét konzisztenciát egyszerre elégítik ki. Ezek már alkalmasak a kockázatkettős kezelésére és fair értékelésére.

Az elméleti megalapozáshoz több forrásból is használtam fel vonatkozó irodalmat. Emellett két példán szemléltettem a piac- és időkonzisztens értékelések alkalmazását, illusztrálva ezzel, hogyan használhatók megközelítéseink konkrét biztosítási szituációkban. Végül kitértem arra, hogy a bevezetett módszerünk milyen, biztosítók számára rendkívül hasznos gyakorlati jelentőséggel bír. A gondolat, hogy a tartam ideje alatt, köztes időpontokban is reagálni lehessen egy biztosítási folyamat alakulására, a klasszikus aktuáriusi árazási elvekben rendszerint nem jelent meg, a bevezetett piac- és időkonzisztens értékelésekben viszont már igen. Ez utóbbi azt is alátámasztja, hogy valóban van létjogosultsága a megismertetett módszereink tanulmányozásának és biztosítói alkalmazásának.

\section{IRODALOMJEGYZÉK}

Møller, T. (2003): Indifference pricing of insurance contracts in a product space model, Finance Stochast, 7: 197-217, https:// doi.org/10.1007/s007800200086

Pelsser, A. - Salahnejhad Ghalehjooghi, A. (2015): Time-Consistent Actuarial Valuations, https://doi.org/10.2139/ssrn.2614002 Pelsser, A. - Stadje, M. (2014): Time-Consistent and Market-Consistent Evaluations

Wuthrich, M.V. - Buhlmann, H. and Furrer, H. (2007): Market-Consistent Actuarial Valuation, Springer International Publishing 